\title{
FUNCTIONALITY OF SAINT PETERSBURG HISTORIC GROUPS OF BUILDINGS FOR ARRANGEMENT OF BUSINESS TOURISM EVENTS
}

\author{
Alexandra Perova \\ Chair of design of architectural milieu, Saint Petersburg State University \\ of Architecture and Civil Engineering, \\ Vtoraja Krasnoarmejskaja ul. 4, St. Petersburg, 190005, Russia \\ alexandra.perova@gmail.com
}

\begin{abstract}
The paper demonstrates that the fractional infrastructure of establishments has been developed within Saint Petersburg to-date suitable for arrangement of business tourism events and capable of servicing each of three business tourists main groups (state, corporate / associate and individual levels). It differs from many other European congress cities with intensive use of historic and adapted buildings. The paper reviews existing historic buildings of Saint Petersburg built in the $18^{\text {th }}-19^{\text {th }}$ centuries with the point of possible use in terms of business tourism events arrangement. The structure of such buildings' main premises was reviewed for the purpose of their intended use for conferences, meetings, exhibitions, etc. It is shown that the existing potential of historic buildings and groups of buildings is considerably actual; there are prospects of their use as well as limitations of such possibilities.
\end{abstract}

\section{Keywords}

Saint Petersburg architecture, business tourism establishments, historic buildings and groups of buildings, functional zoning, congress and exhibition activities.

\section{Introduction}

Industry of business tourism is one of the most fast-growing and highly profitable branches of the global economy. About $40 \mathrm{mln}$ events with the participation of around 2 bln people are being held in this segment. Annual investigations carried out by World Tourism Organization (WTO) show that the share of business tourists within the overall world tourist flow is about $15 \%$, however "up to $60 \%$ of overall tourism turnover is accounted for business tourists". Business meetings industry yields the big cities 4 (four) times higher revenues, rather than arrangement of other social public events.

In the course of this investigation it was established that fractional infrastructure of establishments has been developed within Saint Petersburg to-date, which is capable of servicing each of three business tourists main groups (state, corporate / associate and individual levels). It differs from many other European congress cities with intensive use of historic and adapted buildings. This paper considers the possibility of using the following types of historic buildings for the purposes of business tourism: palaces, mansions, theatres, maneges, libraries.

\section{Materials and methods}

Comprehensive approach forms the methodological foundation for the investigation and includes classification and synthesis of the results obtained in the course desktop study of existing buildings, such as Saint Petersburg palaces, mansions, theatres, maneges and libraries, by main typological features and qualitative characteristics in order to review architectural concepts of these buildings and identify their abilities to be used for arrangement of business tourism events.

\section{Results}

As of today, there is an assemblage of establishments in Saint Petersburg available for hosting business tourism events which is described with the wide variety of building types constructed during different period of times and having different capacity and scope of services provided.

Historic buildings of Saint Petersburg are widely used for arrangement of business tourism events. It 
is due to the fact that these types of buildings include premises exhibiting characteristics suitable for arrangement of business tourism events. Besides that, these buildings are very highly attractive in terms of the quality of historic interiors and location in the downtown. The following types of buildings are considered as historic buildings and group of buildings suitable for the purposes of business tourism events: palaces, mansions, theatres, maneges, libraries built within the pre-revolutionary period.

Considering the premises these buildings consist of, they can be used for the purpose of hosting conferences, exhibitions, symposia, presentations, special events and other business tourism events. Based on the investigation results, Summary Table 1 is generated to describe the types of historic buildings and group of buildings suitable for arrangement of business tourism events in Saint Petersburg.

\subsection{Palaces}

During the pre-revolutionary period palaces were considered as ceremonial residences of Emperors' or upper class representatives. Palaces also played a role of significant cultural and business centers: ceremonies, honorable receptions, balls, festive events and assemblies took place there, as well as meetings of state authority bodies.

After the revolution 1917, the main function of palaces was abolished, no new palaces were constructed and the bodies of soviet authorities, administrative and social organizations, museums were housed in existing palaces (Kirikov, Andreeva, Shmeleva, 2003).

Palaces of Saint Petersburg can be classified as follows:

- in terms of size: large (capacity of the largest room is $500-960$ persons), medium (capacity of the largest room is $250-500$ persons), small (capacity of the largest room is up to 250 persons);

- in terms of type: city or country.

Palaces located in historical center of Saint Petersburg are included into the ribbon building or deep within the site with an open space at the front door (Bunin, Savarenskaya, 1979). Due to the lack of surrounding recreation space, city palaces may have small gardens.

Palaces in suburbs of Saint Petersburg Petergof, Tsarskoye Selo (Tsar's Village) - are larger in terms of capacity. They are very popular among facilitators of business events, especially in summer. The specific feature of country palaces is the availability of recreation space i. e. surrounding parks with small palaces, pavilions, fountains, park arrangements. Isolated park pavilions can be very convenient for negotiation purposes.

Activities related to business tourism are carried out in such palaces as the Tauride palace (architect I.E. Starov, 1783-1789; rebuilt by A.R. Bakh in 1905-
1906), the Palace of Bezborodko the chancellor Central museum of communication named after A.S. Popov (architect D. Quarenghi, 1783-1795; rebuild and restored in 2000-2003), the Palace of Grand Duke Vladimir Alexandrovich - House of Scientists (architect A.I. Rezanov, 1764-1772), the Catherine Palace in Tsar's Village (architect B.F. Rastrelli, 1752-1756; reconstructed after the Great Patriotic War in 1957-1980s by architect A.A. Kedrinskiy), the Petergof Grand Palace (architect J.-F. Braunstein, J.-B. Le Blond, N. Michetti, 17101724; reconstructed after the Great Patriotic War in 1971-1990s) (Petrov, Petrova, Raskin, 1983).

The specific feature of the palaces included into Saint Petersburg business tourism infrastructure is the compliance of functional structure to major requirements applicable to the event site.

These palaces have the entry zone with large entrance hall and lobby, availability of multi-functional rooms of various capacity: from study rooms for several persons up to large rooms for several hundreds of participants. There are restaurants in the palaces or it is possible to arrange catering service.

It is possible to arrange state (federal or regional) and corporate or associate summits, congresses, symposia, conferences, negotiations, exhibitions, special events, banquets in historic places depending on the level of safety.

The main advantage of the palaces is their magnificent interiors. The possibility to hold an event in a ceremonial atmosphere is their unique feature. However, these buildings exhibit some deficiencies preventing them from being the same worth as upto-date centers:

1. Engineering constraints. Palaces arrangements are not suitable for placing numerous technical facilities and units (simultaneous translation equipment, acoustic systems, and climate control systems). Besides, machinery can be harmful for historic atmosphere of palaces' rooms. Arrangement of events is highly regulated due to specific nature of these premises and required long-term finalization.

2. Rooms of the palaces are not capable of being transformed.

3. Insufficient servicing for convenient staying of a business tourist. Absolute lack of extra servicing.

4. Limited capacity. The Duma room of Tauride palace is the largest one in terms of capacity (960 persons). Most of the palaces have rooms with the capacity below 250 people.

The Congress Palace (former Konstantin Palace) located in Strelna can be the example of the palace most complying with up-to-date requirements to arrangement of business events.

As a result of large-scale reconstruction completed in 2003 , a contemporary complex was created within the historic area which is the most 
exclusive place for hosting business events in the North-West region. This place was used to carry out G8 and G20 summits. Numerous rooms, developed infrastructure and up-to-date technology support effective activities. However, the Palace of Congresses has considerable limitation in terms of arrangement of business tourism events. This complex is mainly intended for meetings at the higher state level. Besides, the capacity of its largest room is relatively small and equals to 270 persons only. (N. Michetti, 1720; F. Rastrelli, 1750; reconstructed in 2003).

\subsection{Mansions}

During the pre-revolutionary period city mansions were private houses intended for wealthy families of higher societies to live in. As opposed to the palaces, mansions are more compact and they were mainly functioned as residential buildings. On relatively small occasions they were used to host festive events, meetings, ball events, celebrations [37]. Nowadays mansions are the places for administrative and public organizations and museums.

Mansions buildings in Saint Petersburg differ by great variety of space, lay-outs and artistic solutions. "Their architectural composition and finishing depended on social and financial status of the customer, his family needs and personal preferences. So the range of mansions architectural variety was great: from luxurious palazzo in the downtown to modest one-storey buildings in the outskirts" (Punin, 2009).

Mansions are used for the purpose of business tourism, if their functional structure is in compliance with the main requirements (availability of front entry door - entrance hall and lobby, multi-purpose rooms, possibility to arrange restaurant / banquet room / catering); areal location; attractive exterior and interior of the mansion [46, pp. 35-37]. The following mansions are the most popular ones for the purpose of business meetings arrangement: mansion of M.F. Kseshinskaya - State museum of Russian political history (architect A.I. von Hogen, 1904-1906), mansion of A.A. Polovtsov (the House of Architect) (architect A.C. Pel, 1835-1836).

The advantage of Saint Petersburg mansion is its high executive class. The deficiencies are as following: engineering constraints, lack of possibility to transform the rooms, insufficient extra service, limitation in capacity (rooms are compact and their average capacity is about $100-150$ persons).

\subsection{Theatres}

Theaters in Saint Petersburg appeared from the second half of the $18^{\text {th }}$ century in order to exercise entertaining functions (Punin, 2009). The core of a theater is a large audience space with 250-2,000 seats. Besides, theater buildings are equipped with some additional functional areas (large entrance hall; cloak room; entrance lobby; canteen / restaurant / banquet room) which make this type of establishment suitable for arrangement of congress events. New stage of the Mariinsky Theatre in Saint Petersburg was constructed with consideration of possible business tourism events.

The following classification may be suitable for theatres: in terms of capacity, it terms of construction time (historic or modern).

The following theatres are among the most actual ones for business tourism events: new stage of the Mariinsky Theatre (architect Jack Diamond AB Diamond and Schmitt Architects, 2008-2013), the Hermitage theatre (architect D. Quarenghi, 17831787; reconstructed in 1991).

Theaters may be used for hosting of large state, corporate and associate forums and congresses with up to 2,000 participants.

Theatre sites in Saint Petersburg differ from palaces and mansions by technical support: their specific technical equipment is intended for main function - i.e. entertaining. The deficiency is in difficulty or, in most cases, impossibility of audience space transformation, change in audience seats arrangement for specific event. Theatres are not able to be used as centers of business tourism in continuous mode due to their main function and may be only used on special occasions.

\subsection{Maneges (or riding halls)}

The first Manege in Saint Petersburg was built in 1756-1759 for the First Cadet Corps. Initially maneges were intended for horse riding trainings: horse schooling, ceremonial horse dressing-out. However, maneges lost this function with time.

Currently 2 (two) buildings are used as the objects where business events are taken: Manege of the First Cadet Corps and Mikhailovsky Manege. Each of these maneges is specialized in hosting specific events.

Manege of the First Cadet Corps is a trendy site intended for cultural and business as well as leisure events and is equipped with high-end up-todate equipment (architect J. Borkhard, 1756-1759; reconstructed into the multi-purpose room in 20032005).

Mikhailovsky Manege is the place for exhibitions and it was used as such even in the pre-revolutionary period: Exhibition of Imperial Russian Society of Gardeners in mid. $19^{\text {th }}$ century, The $1^{\text {st }}$ All-Russian Hygiene Exhibition, first automotive exhibitions, in 1909 - International Show of Modern Inventions (Nikitin, 2004).

In 1950s the building subjected to internal redevelopment and was adapted for Winter Stadium. Currently Mikhailovsky Manege is a multipurpose house and it still used for the purpose of sport competitions. The site is also used as a place for exhibitions, arrangement of city cultural and 
business as well as leisure events, conferences (architects V. Brenna, C.G. Rossi, 1798-1800, 1824; reconstructed in 1974).

The Horse Guards Manege was adapted for a garage during Soviet time and in 1967 it was passed to Union of Artists in order to host exhibitions. Occasionally it was used as the place for cultural and business as well as leisure events. Currently the building of the Horse Guards Manege is under overall reconstruction and repair aimed at creation of up-to-date world class exhibition house (architect D. Quarenghi,1804-1807; overall reconstruction and repair started in 2013).

Rooms of former maneges are suitable for holding various event: forums, congresses, banquets, festive events at the corporate / associate level. The advantage of these houses is their ability of being easily transformed as well as their capacity (the area of the Horse Guards Manege and Mikhailovsky Manege is about 4,400 sq.m). The deficiency is complete lack of extra and related services.

\subsection{Libraries}

The first library in Saint Petersburg was the Imperial Public Library (currently - National Library of Russia). It was built in 1795. Generally, libraries, besides their intended use as a book storeroom, served as particular cultural center, where lectures, exhibitions, evening events were taken. Nowadays, available space of libraries makes them suitable for hosting business tourism events.

Libraries of Saint Petersburg subject to the following classification: of federal importance (The National Library of Russia, Boris Yeltsin Presidential
Library), of city importance (Central City Public Library named after $\mathrm{V}$. Mayakovsky), of regional importance.

Libraries of federal importance are suitable for business events to the fullest extent. They have larger rooms and higher level of technical support.

Boris Yeltsin Presidential Library is located in Synode building reconstructed with consideration of social and business function: a roof was created above the inner yard and an atrium was arranged a room intended for round and ordinary conferences with participation of about 300 persons.

The area of multi-purpose multimedia center of the Presidential Library is intended for arrangement and carry out of lectures, video presentations and workshops.

There is an exhibition area which is intended for joint exhibitions with participation of museums, libraries and universities (architect C.G. Rossi, 1829-1836; reconstructed in 2007-2009)

Libraries host corporate / associate subject conferences, presentations and scientific workshops with participation of up to 300 persons. Boris Yeltsin Presidential is the only library in Saint Petersburg taking state conferences, symposia, exhibitions. Except for the Presidential Library and the National Library of Russia, all other libraries do not meet particular requirements, so their use for takin events is limited.

\section{Summary}

In the course of the performed investigation it was observed that the structure of numerous historic groups of buildings involved into hosting

Table 1

Description of buildings and buildings groups with functional zoning adapted for hosting business tourism events. Saint Petersburg

\begin{tabular}{|c|c|c|c|}
\hline $\begin{array}{c}\text { Type of } \\
\text { Establishment }\end{array}$ & Examples of Establishments & Main Premises & Present-Day Use \\
\hline 1 & 2 & 3 & 4 \\
\hline \multirow{4}{*}{ Palace } & & $\begin{array}{l}\text { Residential } \\
\text { premises }\end{array}$ & - \\
\hline & & $\begin{array}{l}\text { Ceremonial } \\
\text { rooms }\end{array}$ & $\begin{array}{l}\text { Social and business } \\
\text { function (symposia, } \\
\text { conferences, exhibitions, } \\
\text { banquets) }\end{array}$ \\
\hline & & Study-rooms & Negotiations \\
\hline & $\begin{array}{l}\text { Konstantine's palace } \\
\text { N. Michetti (1720), } \\
\text { F. Rastrelli (1750), } \\
2003 \text { - reconstruction }\end{array}$ & $\begin{array}{l}\text { Parks, gardens and } \\
\text { relative pavilions }\end{array}$ & $\begin{array}{l}\text { Negotiations is pavilions } \\
\text { located in parks }\end{array}$ \\
\hline
\end{tabular}




\section{Architecture and Engineering Volume 1 Issue 1}

Table 1. Continued

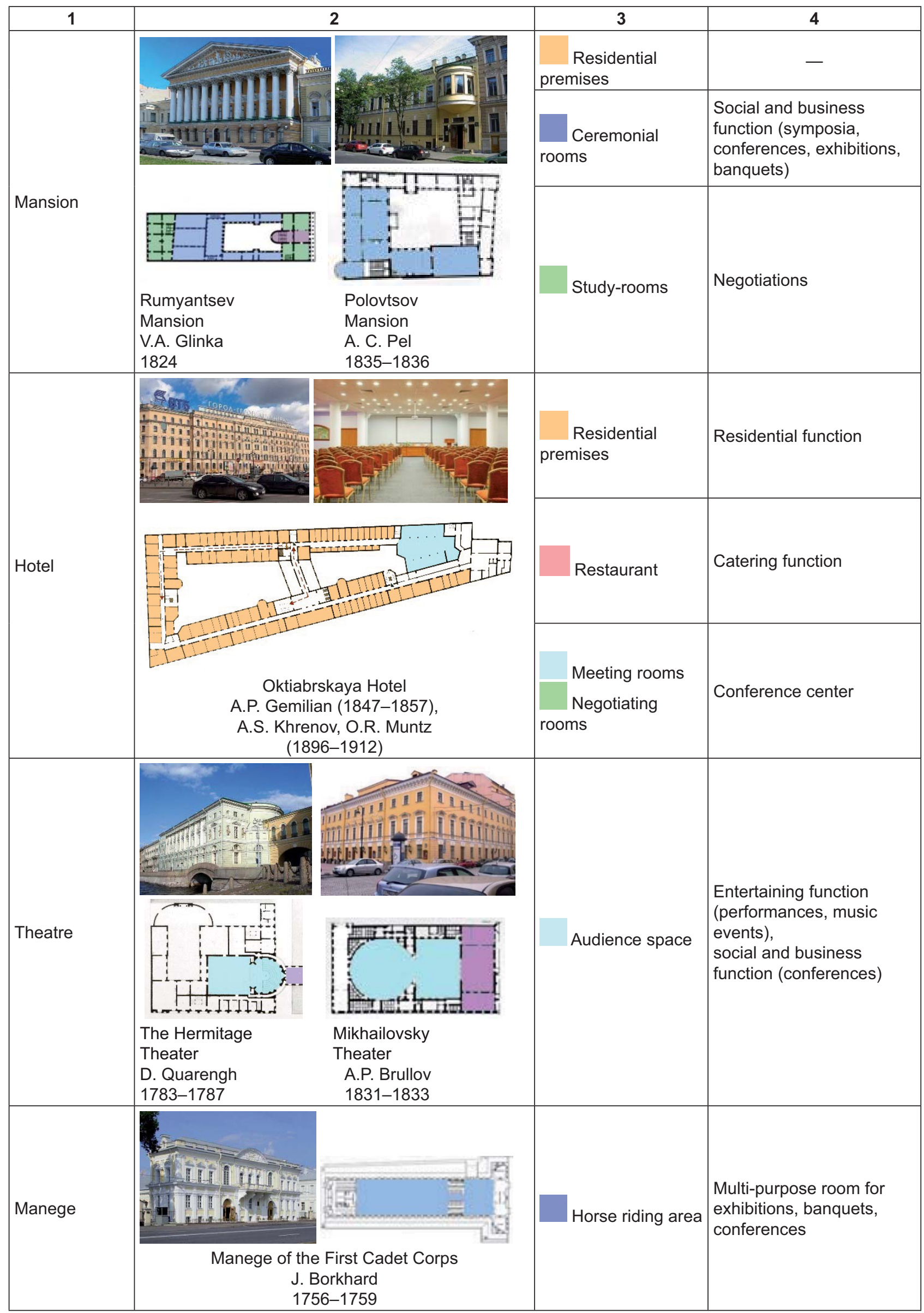


Table 1. Continued

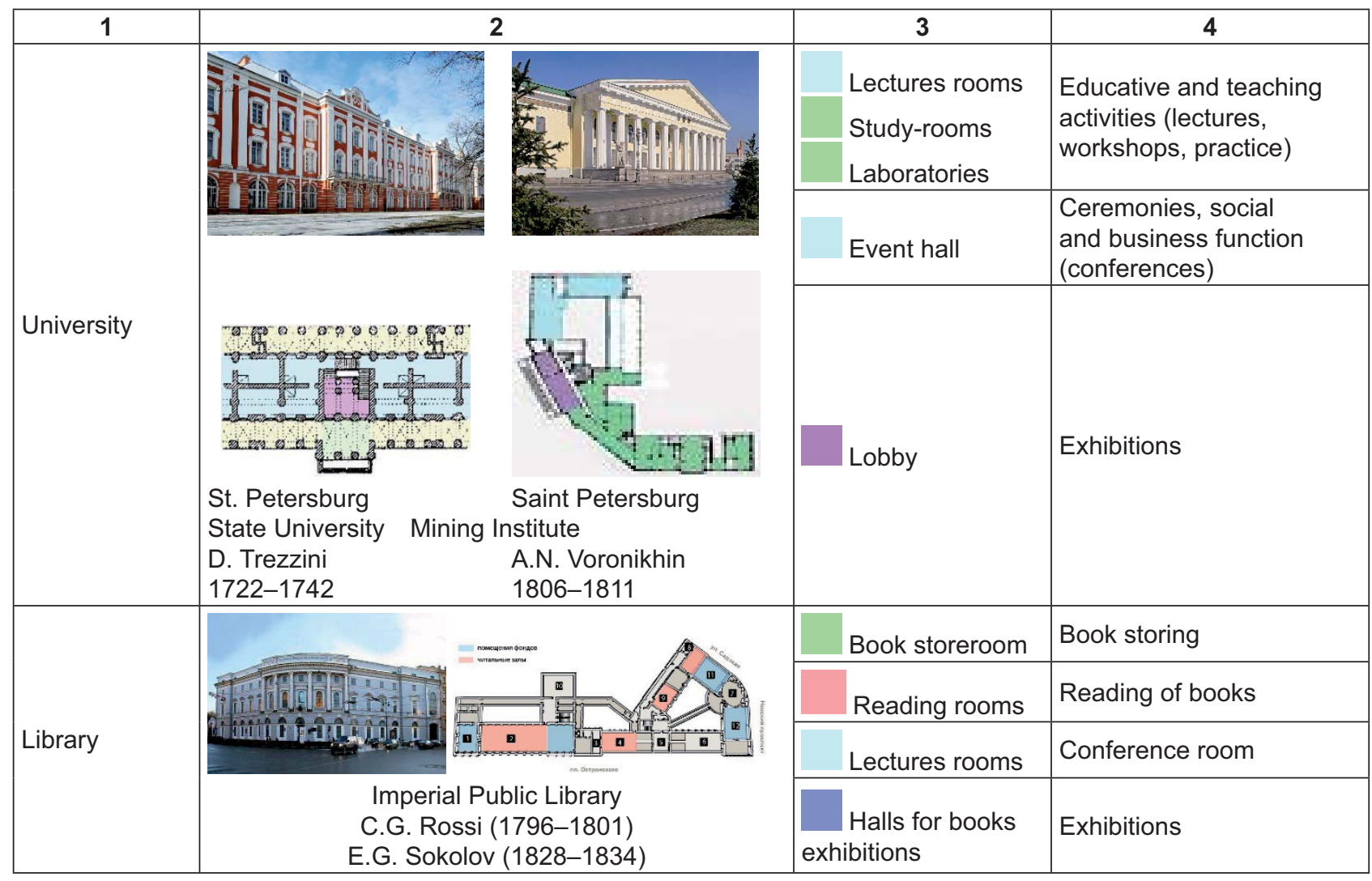

of business tourists' events is out of date and requires architectural and technical upgrade with consideration of trends in the world experience. The availability of large amount of adapted buildings explains low rating of our city among congress cities. However, adapted buildings have found their business segment at the market as the places for arrangement of business events due to their appeal to historic interiors, famous names and location in the downtown.

\section{References}

Bunin A. V., Savarenskaya T.F. (1979) Istoriya gradostroitel'nogo iskusstva [History of urban planning art], 2 vols. $2^{\text {nd }}$ rev. Stroyizdat, Moscow (In Russian)

Kirikov B.M., Andreeva V.I., Shmeleva O. A. (2003) Pamyatniki istorii i kul'tury Sankt-Peterburga, sostoyashchie pod gosudarstvennoy okhranoy [Historical and cultural monuments of Saint Petersburg under state preservation]. Alt-Soft. Saint Petersburg. (In Russian)

Nikitin Yu. A. (2004) Promyshlennye vystavki Rossii XIX - nachala XX veka [Industrial exhibitions in Russia, $19^{\text {th }}-$ early $20^{\text {th }}$ centuries], research publication. Polygraphist, Tcherepovets. (In Russian)

Petrov A.N., Petrova E.N., Raskin A.G. (1983) Pamyatniki arkhitektury prigorodov Leningrada [Architectural moments of Leningrad outskirts]. Stroyizdat. Leningrad division. Saint Petersburg. (In Russian)

Punin A. L. (2009) Arkhitektura Peterburga serediny i vtoroy poloviny XIX veka [Petersburg architecture in mid and the second half of the 19th century]. Kriga, Saint Petersburg (In Russian) 